\title{
Örgütsel Kariyer Yönetiminin Duygusal Bağlılık Üzerindeki Etkisinde İş Tatmininin Aracılık Rolü
}

\author{
Ozan BÜYÜKYILMAZ \\ Sorumlu Yazar, Karabük Üniversitesi, İsletme Fakültesi, \\ Işletme Bölümü, ozanbuyukyilmaz@karabuk.edu.tr \\ İsmail KARAKULLE \\ Kastamonu Üniversitesi, Devrekani Meslek Yüksekokulu, \\ Büro Yönetimi ve Yönetici Asistanlı̆̆ıProgramı, ikarakulle@kastamonu.edu.tr \\ İsmail KARATAŞ \\ Bartın Üniversitesi, Beden Eğitimi ve Spor Yüksekokulu, \\ Beden Eğitimi ve Spor Öğretimi Bölümü, ikaratas@bartin.edu.tr
}

\begin{abstract}
$\ddot{O} \mathbf{z}$
$\mathrm{Bu}$ çalışma örgütsel kariyer yönetimi, iş tatmini ve duygusal bağllık arasındaki ilişkilere odaklanmaktadır. Çalışmanın amacı çalışanlar tarafından algılanan kariyer yönetimi uygulamalarının, çalışanların örgütleriyle aralarındaki duygusal bağllık seviyesini nasıl etkilediğini belirleyebilmek ve bu etkiye iş tatminin herhangi bir aracılık etkisinin bulunup bulunmadığını tespit etmektir. Bu amaçla Konya ilinde hizmet ve üretim sektöründe faaliyet gösteren farklı işletmelerde çalışan 607 işgörenden yazılı soru sorma (anket) tekniği ile veri toplanmıştır. Hipotezleri test etmek için hiyerarşik regresyon analizi kullanılmıştır. Çalışmanın sonucunda hem genel iş tatmininin hem de içsel ve dışsal iş tatmininin, örgütsel kariyer yönetiminin duygusal bağlılık üzerindeki etkisinde kısmi aracılık rolüne sahip olduğu tespit edilmiştir.
\end{abstract}

Anahtar Kelimeler: Örgütsel Kariyer Yönetimi, Duygusal Bağlılık, İş Tatmini.

JEL Sinıflandırma Kodları: D23, J28

The Mediating Role of Job Satisfaction in the Effect of Organizational Career Management on Emotional Commitment

\begin{abstract}
This study focuses on the relationship between organizational career management, job satisfaction and emotional commitment. The purpose of the study is to determine how career management practices perceived employees effect the level of emotional engagement with their organization and to determine whether the degree of job satisfaction mediates this relationship. For this purpose, data were collected from 607 employees working in different businesses of service and production sector in Konya via survey method. Hypotheses were tested by hierarchical regression analysis. As the result of the study it has been found that both general job satisfaction, internal job satisfaction and external job satisfaction have a partial mediating role in the effect of organizational career management on emotional commitment.
\end{abstract}

Keywords: Organizational Career Management, Job Satisfaction, Emotional Commitment. JEL Classification Codes: D23, J28

\footnotetext{
${ }^{*}$ Extended abstract is presented at the end of the article.
}

Atıfta bulunmak için/Cite this paper:

Büyükyılmaz, O., Karakulle, İ. ve Karataş, İ. (2018). Örgütsel kariyer yönetiminin duygusal bağlılık üzerindeki etkisinde iş tatmininin aracılık rolü. Çankırı Karatekin Üniversitesi IIIBF Dergisi, 8 (1), 1-29. 


\section{Giriș}

Küreselleşmenin artan etkisiyle rekabet koşulları hem işletmeler hem de çalışanlar için önemli bir unsur haline gelmiştir. Yaşanan yoğun rekabet sürecinde örgütlerin nitelikli insan kaynağı ihtiyacı giderek artmakta, bu ihtiyacı karşılamak için örgütlerin sahip olduğu insan faktörünün önemi daha da ön plana çıkmaktadır. Çalışanlar, işletmelerin ve yöneticilerin rekabet üstünlüğü elde etmelerinde sahip olduğu araçlardandır (Doğanalp, 2012, s.1).

Teknolojik gelişmeler bireysel ve örgütsel açıdan birçok değişimi beraberinde getirmiştir. Bu değişim ve gelişme koşulları; örgütlerin çalışan yetkinliklerini ve yeterliliklerini yükseltmesi; çalışan amaçlarının örgütsel amaçlarla uyumlaştırılmasını, örgüt kültürünün benimsetilmesini, örgütün geliştirilmesi, çalışanların örgüte olan bağlılık ve katkısının artırılması gerektiğini göz önüne almalarını zorunlu hale getirmiştir (Tuncer, 2012, s.210).

İşletmelerin sahip oldukları teknolojilere uygun olarak hem organizasyon yapıları hem de çalışan profili uyumlu olmalıdır (Ghani, Jayabalan ve Sugumar 2002, s.158). Çalışanların daha üretken ve verimli hale gelmeleri, ekonomik ve teknolojik gelişmelere ayak uydurabilecek bilgi, beceri ve tecrübelere sahip olabilmeleri için örgütlerde etkin bir kariyer yönetiminin uygulamasını gerektirmektedir.

Kariyer yönetimi, çalışanların kariyer süreçlerinde ilerleyebilmeleri, bu süreçte çalışanların gelişmesine katkı sağlayacak olan gerekli destek ve eğitimi karşılayan, bireysel gelişim devamlılı̆̆ını sağlayan bir süreçtir. Kısaca çalışanların işleri ile ilgili planlamalarıdır. Kariyer yönetimi, sadece çalışanların hedeflerini gerçekleştirmek istedikleri bir araç değildir (Fındıkçı, 2009, s.342).

Kariyer yönetimi, örgütün sektördeki rekabet ortamında diğer paydaşlardan farklı bir yer edinmek için belirlemiş olduğu pazar payı, ekonomik büyüme gibi örgütsel hedeflerinin gerçekleştirilmesini sağlayan en önemli araçlardan biridir. Doğru kariyer yönetimi sistemleriyle, örgütsel ve bireysel hedefler aynı doğrultuda geliştirilerek hem bireyin tatmin edilmesi hem de çalışanların verimliliğinin artması sağlanır. Tatmin olmuş çalışanın motivasyonu artarak işletmeyle bütünleşmesi sağlanır (Kılıç ve Öztürk, 2009, s.46).

Örgütlerin kariyer yönetimi yoluyla çalışanların beklenti ve hedefleri ile örgüt amaç ve hedeflerinin bütünleşmesi çalışanların işlerine duydukları tatmin ve bağl1lıklarının artması sağlanmakta; aidiyet duygusu yükselen çalışan ise kendini bağlı bulunduğu örgüte ait hissetmektedir. İş tatmini sağlanmış olan çalışan, örgüte sadece belirli bir ücret karşılığında yükümlü olduğu çalışma zorunluluğundan ziyade örgütün gelişmesine, yapılan işin kalitesinin ve niteliğinin sürekli artmasına katkı sağlar. Bu durum, çalışanlar arasında örgütsel bağlılığın artmasına yardımcı olarak; nitelikli işgücü, verimlilik, performans ve 
çalışma kalitesine olan etkisi açısından örgütler için hayati öneme sahiptir. Güçlü kariyer yönetim sistemi, çalışanların iş doyumuna ulaşmaları ve örgütsel bağlılığın artmasında geniş katılımlı bir süreç olarak sürekli gelişme halindedir (Şimşek, 1998, ss. 336-337).

$\mathrm{Bu}$ çalışmada, çalışanların duygusal bağlılıklarını arttırmada kariyer yönetiminin nasıl bir etkisinin olduğu, örgütsel kariyer yönetiminin iş tatmini nasıl etkilediği, bunun duygusal bağlliğga etkisinin hangi ölçüde olduğunun belirlenmesi amaçlanmaktadır. Bu doğrultuda temel çalışmanın amacı, çalışanlar tarafından algılanan kariyer yönetimi uygulamalarının örgütleriyle aralarındaki duygusal bağlılık seviyesini nasıl etkilediğini ve bu etkiye iş tatmininin herhangi bir aracılık etkisinin bulunup bulunmadığını tespit etmektir.

Araştırma hipotezleri, üretim ve imalat sektörlerinden anket yöntemi ile toplanan veriler ile doğrulayıcı faktör analizi ve hiyerarşik regresyon analizi kullanılarak test edilmiş ve elde edilen bulgular literatür desteği ile değerlendirilmiştir.

\section{Kuramsal Çerçeve}

\subsection{Kariyer Yönetimi}

Kariyer kavramının çeşitli ve geniş kapsamlı olarak değişik tanımları yapılmaktadır. Kariyer, bireyin iş hayatı süresince belirli bir iş kolunda basamak basamak devamlı olarak sahip olacağı bilgi birikimi, tecrübe ve yeterliliktir (Tortop, 1994, s.92). Bu bakış açısına göre kariyer, bireyin iş yaşamı süresince sahip olduğu konumlarının bütünüdür. Başka bir tanımlamayla kariyer, bireyin kamusal ve özel çalışma hayatında yükselme sağlayacağı, bir kazanım elde etmek niyetiyle izlediği ve sürekli olarak emek harcadığı alandır (Bowin ve Harvey, 2000, s.228). Benzer şekilde, kariyer, bireyin iş yaşamı boyunca elde ettiği kişisel olarak sahip olduğu pozisyonlar bütünü olarak ifade edilebilir (Bingöl, 2016, 335). Yapılan tanımlardan yola çıkacak olursak kariyer kavramı farklı şekillerde fakat benzer anlamları kapsayacak şekilde yorumlanmıştır.

Genel olarak kariyer, bir işletmede veya örgütte çalışanların veya çalışma niyetinde olanların, almış oldukları eğitim, sahip oldukları veya olacakları bilgi, beceri, deneyim, yetkinlik ve yeterliliklerinin iş yaşamı boyunca devam eden bir süreçtir. Kariyer kavramı, çalışanların hayatı boyunca elde ettikleri kazanımlar bütününü ifade ederken aynı zamanda çalışanların bu kazanımları elde etmek istedikleri çalışma ortamını da ilgilendiren bir kavramdır. Başka bir ifadeyle, kariyer yönetimi birey ve örgüt bağlamında gerçekleşen iki boyutlu bir durumdur (Ünver, 2005, s.4).

Kariyer yönetimi; örgütlerde çalışanların merak duydukları çalışma alanlarını, sahip oldukları üstünlükleri, yetenekleri ve zayıflıklarını belirledikleri, örgütte sunulan yükselme ve ilerleme olanakları hakkında bilgi sahibi oldukları ve bunları 
gerçekleştirmek için izledikleri bir yoldur (Noe, 2009, s.400). Aynı zamanda kariyer yönetimi, örgütün ve çalışanların karşılıklı olarak sahip oldukları hedefler, bu hedefleri gerçekleştirmek için beraber belirledikleri makul stratejik hedeflerin uygulanmasıdır (Aytaç, 2005, s.115). Diğer bir tanıma göre kariyer yönetimi, kariyer planlama ve geliştirme süreçlerini de kapsayan, örgüt ve bireyin ihtiyaçlarını karşılayacak şekilde kariyerin planlanması, yönetilmesi ve bunu sağlayacak olan örgütsel boyutun belirlenmesi ve yürütülmesidir (Mayo, 1991, s.69).

Kariyer yönetimini sadece çalışanlar veya sadece örgüt açısından ele almak ve anlamak amaçlanan hedefin eksik ve yarım kalmasına neden olabilmektedir. $\mathrm{Bu}$ nedenle bu kavrama hem çalışan hem de örgütün birbiriyle bir bütünlük içinde planlanarak geliştirilmesi ve yönetilmesi açısından bakmak gerekmektedir. Başka bir ifadeyle bireysel kariyer planlarıyla örgütün belirlemiş olduğu kariyer planlama süreci uyum içinde yürütülerek, örgütsel başarı sağlanırken bireysel hedefler gerçekleştirilebilmekte; iş tatminini sağlanmış olan çalışanların örgütün hedef ve stratejilerini benimsemesiyle ilerleme sağlanabilmektedir. Örgütlerin, çalışanlarının kariyer planlarına ulaşabilmeleri için gerekli desteği sağlamaları, onların ihtiyaçlarını belirleyerek yol haritası çizmeleri, bireylerin örgüte olan bağl1lıklarını arttırabilecek unsurlar arasındadır (Erdoğmuş, 2003, s.15).

\subsubsection{Bireysel Kariyer Yönetimi}

Bireysel kariyer yönetiminin gelişimi bireyin sahip olduğu içsel ve dişsal faktörler ışığında gelişme göstermektedir. Bireyin sahip olduğu bilgi, beceri, tutum ve davranışları bireyin kariyerinin gelişmesinde en önemli aşamanın başında gelmektedir. Bireyler hayatlarına etki eden alanlar geliştikçe ve toplumsal hayatta elde ettikleri tecrübeler arttıkça, kariyer planlarını geliştirmek ve bu doğrultuda kendilerine yeni hedefler belirleyerek bilgi, beceri, tutum ve davranışlarının gelişmesini sağlarlar (Şimşek ve Öge, 2014, s.276).

$\mathrm{Bu}$ doğrultuda sahip olduğu yetkinliklerin farkına varan bireyler, çalışma hayatında elde ettikleri başarıları geliştirerek olmak istedikleri yerlere kariyerlerini planlayarak ulaşmaya çalışırlar. Elde edilen başarılar ve tecrübeler kariyer gelişimi üzerinde oldukça önemli bir etkiye sahiptir. Bireyler sahip oldukları kazanımlar sonucunda çalışma hayatında bir önceki konumlarından ileriye doğru devamlı bir gelişme gösterebilirler. Bu durum hem birey tarafından hem de bulundukları örgüt tarafından gerçekleştirilebilir. Bireysel kariyer yönetimi, örgüt destekli kariyer planlama ve geliştirme ile sağlanabilir. Bireysel kariyer planlama süreci ile örgütsel kariyer planlama süreci uyumlu olan örgütlerde çalışanların örgütten beklentilerinin karşılanması oldukça önemli bir durumdur (Özgen, Öztürk ve Yalçın, 2002, s.179). 


\subsection{2. Örgütsel Kariyer Yönetimi}

Teknolojinin ve bilginin geçmişten günümüze doğru hızlı bir gelişme içinde olması hayatın birçok alanını etkilediği gibi çalışma hayatını da etkilemiştir. Yaşanan bu hızlı gelişme işgücünün niteliğinden, dünya pazarlarına, bilgi ve bilişim teknolojilerinden günümüz örgüt yapılarına kadar bazı köklü değişiklikleri de beraberinde getirmiştir. Bu gelişmeler doğrultusunda, örgütler, devamlılıklarını sağlamak, artan rekabet koşullarına uyum göstermek ve rekabet üstünlüğü elde etmek için mevcut çalışanlarının işgücü verimliliğini ve potansiyellerini geliştirmenin önemini anlamışlardır. $\mathrm{Bu}$ doğrultuda örgütler, çalışanlarına planlanmış kariyer yolları vaat ederek ve iş doyumlarını sağlayarak rekabet üstünlügü elde edebilirler (Şimşek, Çelik ve Akatay, 2016, s.171).

Örgütler açısından bakıldığında bu gelişmeler örgütlerde yeni bakış açısı meydana getirmektedir. Örgütler ne kadar gelişmiş teknolojiye sahip olurlarsa olsunlar, iş süreçlerini günün koşullarına ne kadar uygun yaparlarsa yapsınlar, çalışanların örgüt içinde gelişimini ve geliştirilmesi gerekliliğini göz ardı edemezler. Bir taraftan değişen pazar koşullarına ayak uydurmak diğer taraftan da örgütün üstünlüğünü sağlamak için çalışanların işe olan bağlılık ve tatminini sağlamaları gerekmektedir. Küreselleşme olgusunun giderek artan etkisiyle başa çıkabilmek için çalışanların kariyer planlarını sağlanmalıdır. Rekabetin artması sonucunda örgüte olan bağlılığı sağlamak yapılan teknolojik yenilik ve elde edilen başarıyla eşdeğerdir. Başka bir ifadeyle örgütler, bir taraftan örgütlerinin teknik, ekonomik ve pazar açısından gelişimlerini sağlarken diğer taraftan da çalışanlarının gelişimine önem vermeleri gerekmektedir (Tuncer, 2012, s.207).

Örgütsel kariyer yönetiminde ana amaç, örgütsel ve bireysel etkinlik ve verimliliğinin arttırılmasıyla birlikte çalışanların var olan niteliklerini geliştirerek ilerlemelerini sağlamak ve bunun sonucunda gelecekte örgütletin ihtiyacını giderecek olan yetenekli işgücünü bugünden şekillendirmeyi sağlamaktır. Örgütsel kariyer yönetimi ile çalışanların zayıf ve güçlü yanlarını belirleyerek; gereken eğitimin verilmesi sonucunda zayıflıkların ortadan kaldırılmasi sağlanırken güçlü olan taraflarının daha da geliştirilerek etkinliklerinin arttırılması sağlanmaktadır. $\mathrm{Bu}$ da örgütlerin artan rekabet koşullarında rakiplerine karşı üstünlük sağlamak için önemli bir adım sağlayabilmektedir (Greenhaus, Callanan ve Kaplan, 1995, s.3).

\section{2. İş Tatmini}

1920'lerde araştırılmaya başlanan iş tatmini kavramının önemi, 1940'l1 yıllardan sonra ortaya çıkmaya başlamış ve geçmişten günümüze kadar birçok yazar tarafından çalışanların farklı iş tatmin nedenleri ve örgütlerin iş kültürü anlayışından dolayı değişik şekillerde tanımlanmıştır (Akgündüz, 2013, s.181). 
İş tatmini, çalışanların işlerine karşı ve iş çevresine ilişkin beklenti seviyesindeki duygu, düşünce ve tutumları ile ortaya çıkan sonuçlar arasında yaptı̆̆ değerlendirme sonucunda işine karşı olan davranışlarıdır. Çalışanların değerlendirme sonuçları beklentileri ile uyumlu ise iş tatmini, uyumsuz ise iş tatminsizliği söz konusu olmaktadır (Poyraz ve Kama, 2008, s.147). İş tatmini, çalışanın iş çevresinden, yani yaptığı işten, üstlerinden veya amirlerinden, çalışma ekibinden ve iş organizasyonundan elde etmeye amaçladığ mutluluk sağlayan bir duygudur (Karaduman, 2002, s.70). Başka bir ifade ile iş tatmini çalışanların işten elde ettikleri maddi kazançlar, çalışanların aynı iş ortamında çalışmaktan memnun ve mutlu olduğu çalışma arkadaşları ve bir ürün veya çıktı üretmenin sağladığı mutluluktur (Eren, 2004, s.202).

Yapılan tanımlamalarda görüldüğü gibi iş tatmini, örgüt içerisinde çalışanların bir bütün olarak yaptıkları işler, çalışma arkadaşları, çalışma koşulları ve bunları sağlayacak olan örgütün; çalışanların kendi iç dünyasında elde edeceği beklenti ve bu beklentilerin ne kadarının sağlandığı karşılaştırması sonucunda sahip olacağı mutluluk veya mutsuzluk duygusudur.

$\mathrm{Bu}$ bağlamda örgütsel açıdan iş tatmini, örgütlerin elde etmek istedikleri verimlilik ve kârlılık açısından, örgüt çalışanlarının işlerinden duydukları mutluluk yani tatmin düzeyini sağlamak için; gerekli olan koşulları oluşturmak, devamlılık sağlamak ve rekabet edebilme gücü elde etmeleri açısından önemlidir. Çalışanların iş tatmin düzeylerini etkileyen unsurlar, örgüt tarafından iyi analiz edilmeli ve belirlenmelidir. İş tatmini örgütsel açıdan beşeri ve ahlaki bir zorunluluk olmalıdır. Eğer örgütler büyümelerini gerçekleştirirken sadece ekonomik, teknik özelliklerine ağırlık verip, çalışanları göz ardı ederlerse örgütün elde edeceği başarı durumu eksik kalacaktır. Bunun sonucunda örgüte önemli bir maliyet getirecektir (Erdoğan, 1994, s.378).

Bireysel açıdan ise iş tatmini sağlanmış bir çalışanın örgüte ve işine olan bağlılığ 1 artmakta, artan verimlilik, işe devam, yüksek aidiyet, işten ayrılma düşüncesinin ortadan kalkması gibi örgütün ileriye dönük olarak elde edeceği başarı ve gelişimine önemli bir katk1 sağlayarak, örgütün katlanmak zorunda olduğu ek maliyetleri de ortadan kaldıracaktır. İş tatmini, çalışanların fiziksel ve ruhsal sağlıklarını doğrudan etkilemektedir (Sevimli ve İş̧can, 2005, s.55).

Çalışanların iş tatminlerini etkileyen birçok faktör vardır. Bu faktörlerin önemi, çalışanın işine karşı göstermiş olduğu tutumlarından dolayı etkilenme düzeyine göre farkl1l1k gösterir. Bu faktörler; örgütsel faktörler, grup faktörleri, bireysel faktörler, kültürel ve çevresel faktörler şeklinde sıralanabilir (Duman, 2000, ss. 14-15, Örücü, Yumuşak ve Bozkır, 2006, ss.41-42).

İş tatminini, içsel ve dışsal iş tatmin olarak iki faktörden oluşmaktadır. İçsel iş tatmini, başarı, tanınma, işin kendisi, işin sorumluluğu, yükselme ve terfiye bağlı görev değişikliği gibi öğelerden oluşurken; dışsal iş tatmin, işletme politikası ve 
yönetimi, denetim şekli, yönetici, çalışma ve astlarla ilişkiler, çalışma koşulları, ücret gibi işin çevresine ait öğelerden oluşmaktadır (Weiss, Dawis, England ve Lofquist, 1967, s. 4; Karadağ, Başaran ve Korkmaz, 2009, s. 35).

\section{3. Örgütsel Bağl1lık}

Örgütsel bağl1lık, “çalışanların örgüt amaç ve değerlerine yüksek düzeyde inanması ve kabul etmesi, örgüt amaçları için yoğun gayret sarf etme isteği ve örgütte kalmak ve örgüt üyeliğini sürdürmek için duydukları güçlü bir arzu" şeklinde tanımlanmaktadır (Mowday, Steers ve Porter, 1979, s.226). Örgütsel bağl1lık, "birey ve örgüt arasında algılanan uyumun bir fonksiyonu" anlamına gelmektedir (Bateman ve Strasser, 1984, s.95). Meyer ve Allen (1991) örgütsel bağlılığın psikolojik bir boyuta sahip olduğunu belirterek, çalışanların örgütle ilişkisi ile şekillenen ve örgütün sürekli bir üyesi olma kararı almalarını sağlayan bir davranış olarak tanımlamaktadır (Özdevecioğlu, 2003, s.114).

Örgütsel bağlılık alanında yapılan farklı çalışmalarda, çalışanın örgütle farklı yönlerden bütünleşme derecesini ortaya koyma biçimi olduğunu ve örgütsel bağlılığın üç temel öğesinin olduğu belirtilmektedir. Bunlar (Mowday, Porter ve Steers, 1982, s.27; Eisenberg, Monge ve Miller, 1983, s.181; Reichers, 1985, s.468; Allen and Meyer, 1990, s.8; Nijhof, de Jong ve Beukhof, 1998, s.243):

1. Çalışanın, örgütte devamlı olarak kalma konusunda arzulu bir isteğe sahip olma

2. Çalışanın, örgütün sahip olduğu amaç ve değerlerine karşı yüksek bir inanç ve kabul gösterme

3. Çalışanın, örgütün belirlemiş olduğu hedeflerine ulaşmak için çaba, gayret ve azim gösterme

Bununla birlikte örgütsel bağlılıkla ilgili olarak birçok araştırmacı farklı bağl1lık türü ayrımına gitmişlerdir. Örgütsel bağlllıkla ilgili olarak Etzioni (1975); negatif (yabancılaştırıcı), nötr (hesapçı) ve pozitif (moral) bağlılık, Kanter (1968); devam, uyum ve kontrol bağlılı̆̆ı, O'Reilly ve Chatman (1986); uyum, özdeşleşme ve içselleştirme bağglılığı, Mowday vd. (1979); davranışsal, tutumsal bağlılık, Katz ve Kahn (1977); araçsal ve anlatımsal devre, Wiener (1982); araçsal ve normatif bağlılık, Meyer ve Allen (1991); duygusal, devam ve normatif bağl1lık olmak üzere sınıflandırmışlardır. Bu kapsamda;

Duygusal Bă̆lılık: Örgütlerde çalışanların örgütün belirlediği hedef, plan ve strateji doğrultusunda ve örgütün temel hedeflerine kendilerini duygusal olarak bütünleştirmeleri ve örgütsel işlemlere dâhil olmalarıdır. Örgütte duygusal bağlılığ1 en yüksek seviyede sağlanmış olan çalışan örgüte kalma istekliliği sürekli bir durum meydana getirir (Meyer ve Allen, 1991, s.67). Duygusal bağlılık, örgütlerde çalışanların örgütün belirlemiş olduğu kurallar çerçevesinde örgütün genel işleyişine uymanın da ötesinde çalışanların örgütün gelişmesi, 
varlığını en iyi şekilde ilerletmesi ve rakiplerine karşı üstünlük sağlamada içten gelerek örgütün tüm faaliyetlerine katılmayı kapsayan bir bağll1ık türüdür (Cengiz, 2002, s.805). Örgütlerin genel olarak sahip olmak istedikleri ve arzuladıkları örgütsel bağl1lık türüdür.

Devam Bağlllı̆ğ: Örgütte çalışanların örgütten ayrılmaları sonucunda sahip olduğu ekonomik getirilerden yoksun kalacağı, çalışanların mevcut iş koşullarının sınırlılığ veya hiç olmaması durumunda ayrılmaları sonucunda elde edecekleri gelirlerin kısa sürede elde edememelerinden kaynaklı olarak ayrıca örgütte sağladıkları faydaların boşa gideceği anlayışına dayanarak örgüte olan bağll1ıklarının bir zorunluluk teşkil etmesini ifade eden bağlllık türüdür (Meyer ve Allen, 1991, s.67). Devam bağlılı̆ını etkileyen sebeplerin başında başka iş bulamama, ailevi veya sosyal çevre, emekliliğe az süre kalması, sahip olunan niteliklerle başka iş bulmak için yeterli olmaması, özgüven eksikliğine dayalı işini kaybetme korkusu sayılabilir (Çetin, 2004, s.95). Devam bağlılığı örgütlerin istemedikleri bir durumdur. Çünkü devam bağlllığına yüksek olan çalışanlar örgüte faydadan çok zarar getirmektedir.

Normatif bağlllık: Çalışanların örgütte kalmalarının bir gereklilikten ziyade çalışanların kendilerini ahlaki ve vicdani açıdan zorunlu hissetmeleri durumudur. Normatif bağl1lığı yüksek olan çalışanlar örgütte kalmaları gerektiğini düşünürler (Meyer ve Allen, 1991). Bu tip bağlılık, çalışanların örgüte çalışmaya başlamadan önce sahip oldukları duygularının örgütte geçirdikleri zaman süresi sonucunda örgütte kalmaları için duydukları baskıların tümüdür (Allen ve Meyer, 1990, s.4). Örgütsel bağl1lığın bu boyutunun temeli, çalışanların örgüte karşı hissettikleri sorumluluk ve zorunluluklarından dolayı kendilerini örgütte kalmaya mecbur hissetmeleri düşüncesi nedeniyle ortaya çıkmıştır (Wasti, 2002, s.526).

Genel olarak değerlendirildiğinde, çalışanlar örgütlerine karşı kuvvetli bir duygusal bağll1ık beslediklerinde örgütlerinde kalmak isterken; kuvvetli bir devam bağlılığına sahip olan çalışanlar bazı gerekliliklerden ötürü örgütte kalmaları zorunluğu hissederler, kuvvetli bir normatif bağlllığa sahip olan çalışanlar ise örgütte kalmaları gerektiği için örgütlerinde kalırlar. Bağlılık seviyelerinin etkisi hem çalışan hem de örgüt için farklılık gösterir. Bu durumda örgütün ve çalışanın elde edeceği kazanç ve kayıpların büyüklügü de farklı olacaktır (Bolat ve Bolat, 2008, s.78).

Bununla birlikte, Allen ve Meyer (1990) her ne kadar örgütsel bağl1lığın üç boyutu bulunsa da, bireyin örgüte asıl bağlılığın çalışanın hisleri ve duyguları kapsamında örgütüyle bütünleşmesi, örgütün bir üyesi olmaktan mutluluk duyması olduğunu söylemektedir. Ayrıca Meyer, Stanley, Herscovitch ve Topolnytsky (2002) duygusal bağllı̆ı̆ın çalışan tutum ve davranışları üzerinde diğer bağlllık boyutlarına göre çok daha güçlü bir etkiye sahip olduğunu belirtmektedir. Dolayısıyla duygusal bağl1lığın, örgütsel bağlılık içerisindeki 
temel boyut olduğunu söylemek mümkündür. Bu çerçevede çalışmada duygusal bağlılığa odaklanılmaktadır.

\subsection{Değişkenler Arasındaki İlişkiler ve Hipotezler}

Kariyer yönetimi üzerine gerçekleştirilen araştırmalar, bu tür faaliyetlerin yalnızca zaman kaybı olmadığını kanıtlamaktadır. Örgütünden kariyer desteği alan çalışanlar daha fazla olumlu sonuç üretme eğilimindedir (Sturges, Guest, Conway ve Davey, 2002). Genel olarak araştırmalarda örgütsel kariyer yönetiminin kariyer başarısı ve çalışan performansı üzerindeki etkisi araştırılmaktadır. Orpen (1994) özel ve kamu sektöründeki 129 çalışan üzerindeki araştırma ile kariyer yönetiminin kariyer başarısını olumlu yönde etkilediğini belirlemiştir. Benzer şekilde Yahya, Othman ve Meruda'nın (2004) çalışması bireysel performans üzerinde örgütsel kariyer yönetiminin olumlu bir etkisi bulunduğunu göstermektedir.

Bununla birlikte bazı araştırmalarda örgütsel kariyer yönetimi faaliyetlerinin iş tatminini ne şekilde etkilediği de araştırılmaktadır (Hsiao, 2013; Ay, Filizöz ve Öncül, 2014; Kaya ve Ceylan, 2014). Araştırmalar örgüt tarafından gerçekleştirilen kariyer yönetimi faaliyetlerinin çalışanların kariyer gelişim hedefleri oluşturmalarına yardımcı olacağını ve kendi kariyer gelişimine örgütün katk1 vermesini çalışanların olumlu karşılayacağını göstermektedir. Buna karşılık olarak çalışanların işlerine karşı bilişsel ve duygusal bakışları olumlu yönde etkilenecek ve iş tatminleri artacaktır.

H1: Çalışanlar tarafindan algllanan örgütsel kariyer yönetimi faaliyetleri iş tatminini (Hla:genel iş tatmini, H1b:içsel iş tatmini, Hlc:dışsal iş tatmini) pozitif ve anlaml olarak etkilemektedir.

Kariyer yönetimi ve örgütsel bağlılık arasındaki ilişki de literatürde sıklıkla incelenmektedir (Sturges vd., 2002; Kılıç, 2008; Küçük, 2012; Hsiao, 2013). Temel olarak, yeterli kariyer yönetimi desteği almayan çalışanlar yöneticilerinden memnun kalmayacak ve örgüt dışında firsatlar arayacaktır (Horwitz, Chan ve Quazi, 2003). Dolayısıyla örgütsel kariyer yönetimi faaliyetleri ile örgütsel bağlılık arasında anlamlı bir ilişki bulunmaktadır (Sturges vd., 2002). Çalışan, kendisine zihinsel olarak gelişim firsatı sunulduğunu ve zorlayıcı görevlerle gelişimine destek olunduğunu düşündügünde duygusal olarak örgütüne daha fazla bağlanacaktır (Horwitz vd., 2003; Carleton, 2011). Çalışan, örgütte beceri geliştirme faaliyetleri uygulandığında, örgütünün kişisel gelişimine önem verdiğini anlayacak ve bu olumlu algı çalışanın örgütüne bağlılığını arttıracaktır (Meyer ve Smith, 2000).

H2: Çalışanlar tarafindan algllanan örgütsel kariyer yönetimi faaliyetleri duygusal bağlılı̆̆ pozitif ve anlamlı olarak etkilemektedir. 
Birçok araştırma iş tatmininin örgütsel bağlılık için önemli bir öncül olduğunu belirtmektedir. Günlü, Aksaraylı ve Perçin (2010) tarafından otel yöneticileri üzerinde gerçekleştirilen araştırma içsel, dışsal ve genel iş tatmininin duygusal bağl1lığ1 ve normatif bağlılığı olumlu olarak etkilediğini göstermektedir. Kwantes (2009) tarafından Hintli ve Amerikalı çalışanlar üzerinde gerçekleştirilen araştırmada da genel iş tatmininin hem Hintli hem de Amerikalı çalışanların duygusal bağlılıkları üzerinde pozitif yönlü bir etkisinin bulunduğu tespit edilmiştir. Brown ve Peterson'un (1993) araştırması da iş tatmininin örgütsel bağl1lığın önemli bir öncülü olduğunu kanıtlamaktadır.

H3: İ̧̧ tatmini (H3a:genel iş tatmini, H3b:içsel iş tatmini, H3c:dışsal iş tatmini) duygusal bă̆lılığı pozitif ve anlamlı olarak etkilemektedir.

Belirtildiği üzere, hem örgütsel kariyer yönetimi faaliyetleri (Sturges vd., 2002; K1lıç, 2008; Küçük, 2012; Hsiao, 2013) hem de iş tatmini (Kwantes, 2009; Günlü, 2010) duygusal bağl1lık üzerinde pozitif bir etkiye sahiptir. Bununla birlikte örgütsel kariyer yönetimi faaliyetleri sonucunda iş tatmini artan bir çalışanın duygusal olarak örgütüne daha da fazla bağlanacağı düşünülmektedir. Dolayısıyla iş tatmininin örgütsel kariyer yönetimi faaliyetleri ile duygusal bağl1lık ilişkisine aracılık ettiği söylenebilir.

H4: İ̧̧ tatmini (H4a:genel iş tatmini, H4b:içsel iş tatmini, H4c:dışsal iş tatmini), örgütsel kariyer yönetimi ile duygusal bağlılık arasındaki ilişkiye aracılık etmektedir.

Araştırmanın amacı ve test edilmek istenen hipotezler kapsamında oluşturulan araştırma modeli Şekil 1'de sunulmaktadır.

Şekil 1: Araştırma Modeli

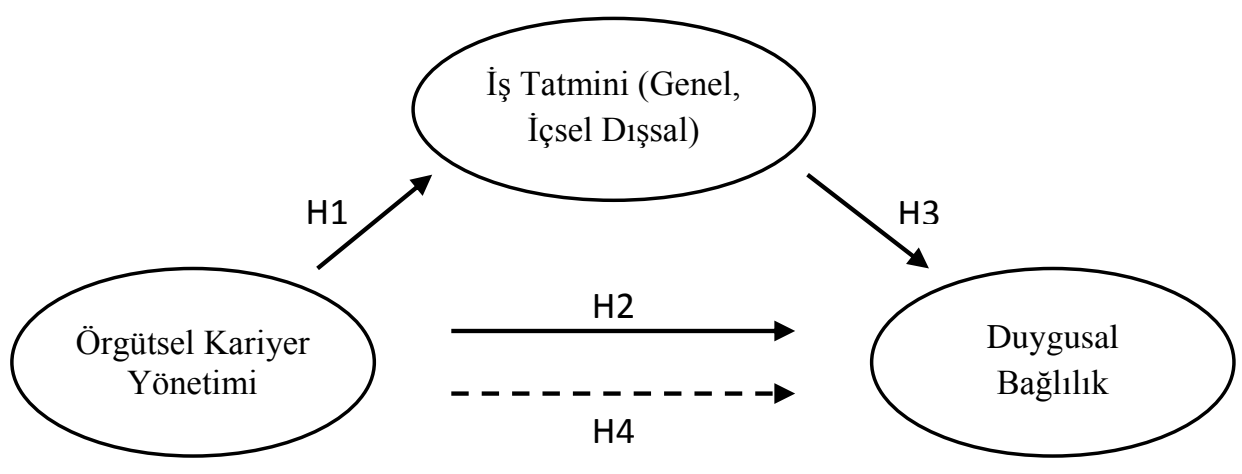




\section{Yöntem}

\subsection{Evren ve Örneklem}

Çalışmanın evrenini, üretim (gıda üretimi, kâğıt üretimi, makina üretimi, yedek parça üretimi, inşaat ve yapı malzemeleri) ve hizmet (perakende, restoran, otel) sektörlerinde faaliyette bulunan işletmelerin farklı seviyelerinde çalışmakta olan işgörenler oluşturmaktadır. İşletmelerden alınan bilgilere göre araştırma evreni 13240 kişiden oluşmaktadır.

Evren içerisinden \%95 güvenilirlik ve \%5'lik bir hata payı ile hesaplanan en düşük örneklem büyüklüğü 374 kişi olarak belirlenmiştir (Sekaran, 2003, s.294; Altunışık, Coşkun, Bayraktaroğlu ve Yıldırım, 2005, s.127). Geri dönüş oranları da dikkate alınarak kolayda örnekleme yöntemi ile üretim sektörü işletmelerindeki 500 ve hizmet sektörü işletmelerindeki 450 çalışana anketler dağıtılmıştır. Toplamda 609 çalışandan geri dönüş sağlanmıştır (üretim işletmelerinden 323, hizmet işletmelerinden 286). Geri dönüş oranı \%64,1 olarak hesaplanmıştır. İnceleme sonucunda 2 anketin geçersiz olduğu belirlenmiştir. Sonuç olarak çalışmanın örneklemi 607 çalışandan oluşmaktadır.

\subsection{Veri Toplama Yöntemi}

Araştırmada veri toplama amacıyla anket (yazılı soru sorma) tekniği kullanılmış, bu kapsamda online anketten yararlanılmıştır. Veri toplama amacıyla hazırlanan anket formu dört bölümden oluşmaktadır. Anketin birinci bölümü, çalışanların demografik özelliklerini belirlemeye yönelik sorulardan oluşmaktadır. Anketin ikinci bölümünde, çalışanların örgütlerinde gerçekleştirilen kariyer yönetimi faaliyetlerini nasıl algıladıklarını belirlemeye yönelik ifadeler yer almaktadır. Anketin üçüncü bölümünde, çalışanların işlerinden duydukları tatmin derecesini belirmeye yönelik ifadelere yer verilmiştir. Anketin dördüncü bölümünde ise çalışanların örgütlerine ilişkin duygusal bağlılıklarının derecelerini belirlemeye yönelik ifadeler bulunmaktadır.

\subsection{Kullanılan Ölçekler}

Çalışma kapsamında belirlenen hipotezlerin test edilmesi amacıyla, daha önce çeşitli çalışmalarda kullanılan ölçekler incelenmiş ve araştırma yapısına uygun olduğu düşünülen ölçekler anket formunda kullanılmıştır.

\subsection{1. Örgütsel Kariyer Yönetimi Ölçeği}

Çalışanlar tarafından algılanan örgütsel kariyer yönetimi faaliyetlerinin derecesini belirleyebilmek için Küçük (2012) tarafından geliştirilen ölçek kullanılmıştır. Örgütsel kariyer yönetimi ölçeği tek boyutludur ve 13 ifadeden oluşmaktadır. Ölçekte ters kodlanmış herhangi bir ifade bulunmamaktadır. Ölçekte " $\mathrm{Bu}$ 
işletmede çalışanların yeteneklerine uygun kariyer firsatları sunulur" ve "Çalıştı̆ı̆m işletmede kariyer planlaması çalışmaları yeterince yapılıyor" gibi ifadeler bulunmaktadır.

Ölçek beşli likert tipi olarak anket formunda yer almaktadır. Ölçek maddeleri " $1=$ Kesinlikle Katılmiyorum", " $2=$ Katılmıyorum", " $3=$ Kararsizım", "4=Katılıyorum" ve " $5=$ Kesinlikle Katılıyorum" şeklinde değişen cevapları içermektedir. Ölçekten elde edilen yüksek skorlar örgütsel kariyer yönetimine ilişkin algının yüksek olduğunu göstermektedir.

\subsection{2. İş Tatmini Ölçeği}

Çalışanların işlerinden duydukları tatmin derecesini belirleyebilmek amacıyla Minnesota İş Tatmini Ölçeği’nden yararlanılmıştır. Minnesota İş Tatmini Ölçeği, 1967 yılında, Weiss vd. (1967) tarafından geliştirilmiş bir ölçektir. Çalışmada ölçeğin 20 sorudan oluşan kısa formu kullanılmıştır. Ölçek iki boyuttan oluşmakta ve 12 soru içsel iş tatmininin, 8 soru ise dışsal iş tatmininin derecesini belirlemek amacıyla kullanılmaktadır. 20 sorunun toplamıyla ise genel iş tatmin derecesi belirlenmektedir. Çalışma kapsamında kullanılan iş tatmini ölçeğinin Türkçesi, Emre (2016) tarafindan gerçekleştirilen çalışmadan alınarak anket formunda kullanılmıştır.

İş tatmini ölçeğinde ölçek maddeleri " $1=$ Hiç Memnun Değilim", "2= Memnun Değilim", "3= Kararsızım", " $4=$ Memnunum" ve " $5=$ Çok Memnunum" şeklinde değişen cevapları içermektedir. Yüksek skorlar, çalışanların yüksek derecede iş tatminine sahip olduğunu göstermektedir.

\subsubsection{Duygusal Bağlllık Ölçeği}

Katılımcıların duygusal bağlılık seviyesini belirleyebilmek amacıyla Allen ve Meyer (1990) tarafından geliştirilen ve Meyer, Allen ve Smith (1993) tarafından revize edilen ölçekten faydalanılmıştır. Duygusal bağlllık ölçeği, örgütsel bağlllık ölçeğinin üç alt boyutundan biridir. Araştırma kapsamında duygusal bağlllığın ölçümü, 18 ifadeden oluşan örgütsel bağlllık ölçeği içerisinde yer alan 6 ifade ile gerçekleştirilmiştir. Ölçeğin Türkçesi, Gürkan (2006) tarafından gerçekleştirilen çalışmadan alınarak anket formunda kullanılmıştır. Ölçekte "Kariyerimin geri kalan kısmını bu örgütte geçirmek beni mutlu eder", "Şu anda, istesem bile bu örgütten ayrılmam benim için çok zordur" ve "Örgütümden şimdi ayrıllırsam kendimi suçlu hissederim" gibi ifadeler bulunmaktadır.

Ölçek beşli likert tipi olarak anket formunda yer almaktadır. Ölçek maddeleri " $1=$ Kesinlikle Katılmıyorum", "2= Katılmıyorum", " $3=$ Görüşüm Yok", " $4=$ Katılıyorum" ve " $5=$ Kesinlikle Katılıyorum" şeklinde değişen cevapları içermektedir. Yüksek skorlar, akademik personelin yüksek derecede duygusal bağll1ı̆̆a sahip olduğunu göstermektedir. 


\subsection{Analiz Yöntemi}

Araştırmada öncelikle çalışma kapsamında kullanılan ölçeklerin geçerliliği ve güvenilirliği test edilmiştir. Örgütsel kariyer yönetimi ölçeğinin, iş tatmini ölçeğinin ve örgütsel bağlılık ölçeğinin yapı geçerliliğini test edebilmek amacıyla doğrulayıcı faktör analizinden yararlanılmıştır. Doğrulayıcı faktör analizi, daha önce keşfedilmiş ve daha az faktör altında birleştirilmiş ölçeklerin, araştırmanın yapıldığ 1 örneklemde de benzer olup olmadığını test etmek amaciyla kullanılmaktadır (Anderson ve Gerbing, 1988, s.412; Byrne, 2010, ss. 5-6; Meydan ve Şeşen, 2011, s. 21). Bu kapsamda araştırmada kullanılan tüm değişkenlerin dâhil edildiği tek bir doğrulayıcı faktör analizi uygulanmıştır.

Geçerlilik analizinin ardından tüm ölçeklerin güvenilirlik analizleri de gerçekleştirilmiştir. Güvenilirlik analizi kapsamında ölçeklerin içsel tutarlılığını belirleyebilmek için Cronbach Alfa $(\alpha)$ istatistiğinden yararlanılmıştır. Çalışmada yer alan hipotezler ise hiyerarşik regresyon analizi ile test edilmiştir

\section{Bulgular}

Bulgular başlığında öncelikle araştırmaya katılan örneklemin demografik özelliklerine, daha sonra ise sırasıyla geçerlilik ve güvenilirlik analizlerine, tanımlayıcı istatistiklere ve hipotez testlerine değinilmektedir.

\subsection{Demografik Bilgiler}

Araştırma örnekleminin cinsiyet, medeni durum, yaş, öğrenim durumu, aylık gelir, işyerinde çalışma süresi ve pozisyon değişkenlerine göre dağılımı Tablo 1 'de gösterilmektedir.

Tablo 1 incelendiğinde örneklemin büyük çoğunluğunun erkek (\%70.3) ve evli (\%71.3) çalışanlardan oluştuğu görülmektedir. Katılımcıların yaşları incelendiğinde 31-40 arası çalışanların daha büyük oranda olduğu belirlenmiştir (\%51.7). Öğrenim durumlarına bakıldığında \%21'inin önlisans, \%49.8'nin lisans, $\% 27,8$ 'nin yüksek lisans mezunu olduğu, lise ve altı mezuniyet derecesine sahip olanların \%0.8 olduğu görülmektedir. Dolayısıyla, katılımcıların öğrenim seviyesinin yüksek olduğu söylenebilmektedir. Aylık gelire bakıldığında, katılımcıların büyük çoğunluğunun 3001TL ve daha fazla gelire sahip olduğu tespit edilmiştir (\%78.4). İşyerinde çalışma sürelerine bakıldığında \%11.7'si 1 yıldan az süredir, \%25.7'si 1-3 yı1, \%22.2'si 4-6 y11, \%16.6's1 7-10 y1l, \%11.5'i 11-14 y1l ve \%12.3'ü 15 y1l ve daha fazla süredir mevcut işletmelerinde çalışmaktadır. Son olarak pozisyonlarına bakıldığında \%12,5'inin üst kademe yönetici, \%17,5'inin orta kademe yönetici, \%37.4'ü alt kademe yönetici ve \%30.3’ü işgören olarak işletmesinde görev yapmaktadır. Katılımcıların \%2.3'ü ise işletmesinde diğer pozisyonlarda görev yaptığını belirtmiştir. 
Tablo 1: Demografik Özellikler

\begin{tabular}{|c|c|c|c|c|c|c|c|}
\hline Değişken & Kategori & $\mathbf{N}$ & $\%$ & Değişken & Kategori & $\mathbf{N}$ & $\%$ \\
\hline \multirow{2}{*}{ Cinsiyet } & Erkek & 427 & 70.3 & \multirow{4}{*}{ Yaş } & 30 yaş ve alt1 & 135 & 22.2 \\
\hline & Kadın & 180 & 29.7 & & $31-40$ yaş aras1 & 314 & 51.7 \\
\hline \multirow{2}{*}{$\begin{array}{l}\text { Medeni } \\
\text { Durum }\end{array}$} & Evli & 433 & 71.3 & & $41-50$ yaş arası & 143 & 23.6 \\
\hline & Bekâr & 174 & 28.7 & & 51 yaş ve üstü & 15 & 2.5 \\
\hline \multirow{4}{*}{$\begin{array}{l}\text { Öğrenim } \\
\text { Durumu }\end{array}$} & Lise ve alt1 & 5 & 0.8 & \multirow{4}{*}{$\begin{array}{l}\text { Aylık } \\
\text { Gelir }\end{array}$} & 2000 TL ve alt1 & 14 & 2.3 \\
\hline & Önlisans & 131 & 21.6 & & 2001-3000 TL aras1 & 117 & 19.3 \\
\hline & Lisans & 302 & 49.8 & & 3001-4000 TL aras1 & 198 & 32.6 \\
\hline & Lisansüstü & 169 & 27.8 & & 4000 TL ve üstü & 278 & 45.8 \\
\hline \multirow{6}{*}{$\begin{array}{l}\text { İşyerinde } \\
\text { Çalışma } \\
\text { Süresi }\end{array}$} & 1 yildan az & 71 & 11.7 & \multirow{5}{*}{ Pozisyon } & $\begin{array}{l}\text { Üst Kademe } \\
\text { Yönetici }\end{array}$ & 76 & 12.5 \\
\hline & $1-3$ y1l aras 1 & 156 & 25.7 & & $\begin{array}{l}\text { Orta Kademe } \\
\text { Yönetici }\end{array}$ & 106 & 17.5 \\
\hline & 4-6 yıl arası & 135 & 22.2 & & $\begin{array}{l}\text { Alt Kademe } \\
\text { Yönetici } \\
\end{array}$ & 227 & 37.4 \\
\hline & 7-10 yıl aras1 & 101 & 16.6 & & İşgören & 184 & 30.3 \\
\hline & $11-14$ yıl aras1 & 70 & 11.5 & & Diğer & 14 & 2.3 \\
\hline & 15 yıl ve daha fazla & 74 & 12.3 & \multicolumn{2}{|c|}{ TOPLAM } & 607 & 100 \\
\hline
\end{tabular}

\subsection{Geçerlilik ve Güvenilirlik Analizleri}

Araştırmada ölçeklerin yapı geçerliliği doğrulayıcı faktör analizi ile test edilmiştir. $\mathrm{Bu}$ amaçla araştırmada kullanılan bütün değişkenlerin birlikte yer aldığı tek bir doğrulayıcı faktör analizi uygulanmıştır. Model uyumu ki kare uyum testi ( $\left.\chi^{2} / \mathrm{sd}\right)$, uyum iyiliği indeksi (GFI), normlandırılmış uyum indeksi (NFI), Tucker-Lewis indeksi (TLI), karşılaştırmalı uyum indeksi (CFI) ve yaklaşık hataların ortalama karekökü (RMSEA) aracılığıyla incelenmiştir.

Gerçekleştirilen doğrulayıcı faktör analizi sonucunda, duygusal bağlılık ölçeğindeki bir ifadenin faktör yükünün 0.40 'ın altında olduğu belirlenmiştir ve ifade analiz dışında bırakılmıştır. Doğrulayıcı faktör analizi sonuçları Tablo 2'de gösterilmektedir.

Tablo 2'ye göre örgütsel kariyer yönetimi ölçeğinin faktör yükleri 0.817 ile 0.938 arasında, duygusal bağlılık ölçeği için faktör yükleri 0.402 ile 0,935 arasında içsel iş tatmini için faktör yükleri 0.599 ile 0.801 arasında ve dışsal iş tatmini için faktör yükleri 0.617 ile 0.819 arasında değişmektedir. 
Tablo 2: Doğrulayıcı Faktör Analizi Sonuçları

\begin{tabular}{|c|c|c|c|c|c|c|c|}
\hline Maddeler & $\begin{array}{c}\text { Faktör } \\
\text { Yükü }\end{array}$ & $\begin{array}{l}\text { Standart } \\
\text { Hatalar }\end{array}$ & t-değeri & Maddeler & $\begin{array}{c}\text { Faktör } \\
\text { Yükü }\end{array}$ & $\begin{array}{l}\text { Standart } \\
\text { Hatalar }\end{array}$ & t-değeri \\
\hline \multicolumn{4}{|c|}{ Örgütsel Kariyer Yönetimi Ölçeği } & \multicolumn{4}{|c|}{ İş Tatmini Ölçeği } \\
\hline ÖRKAR1 & 0.928 & - & - & İÇİŞTAT1 & 0.599 & - & - \\
\hline ÖRKAR2 & 0.919 & 0.020 & 51.258 & İÇișTAT2 & 0.657 & 0.106 & 14.467 \\
\hline ÖRKAR3 & 0.817 & 0.034 & 29.939 & İÇișTAT3 & 0.666 & 0.120 & 13.575 \\
\hline ÖRKAR4 & 0.935 & 0.025 & 43.810 & İÇİŞTAT4 & 0.644 & 0.083 & 13.240 \\
\hline ÖRKAR5 & $\mathbf{0 . 9 3 3}$ & 0.026 & 43.514 & İÇİŞTAT5 & 0.670 & 0.103 & 13.622 \\
\hline ÖRKAR6 & 0.938 & & & İÇIŞTAT6 & 0.737 & 0.086 & 14.592 \\
\hline ÖRKAR7 & 0.916 & 0 . & 40.878 & İÇIŞTAT7 & 0.699 & 0.105 & 14.050 \\
\hline ÖRKAR8 & 0.913 & & & İÇiș & 0.758 & 99 & 14.864 \\
\hline ÖRKAR9 & $\mathbf{0 . 8 8 7}$ & & 01 & İÇiş̦ & 0.801 & 01 & 15.422 \\
\hline ÖRKAR10 & 0.846 & 0.032 & 32.488 & İÇİŞTAT10 & 0.747 & 0.105 & 14.725 \\
\hline ÖRKAR11 & 0.913 & 0.027 & 40.412 & İÇ̧̇̇ŞTAT11 & 0.746 & 0.103 & 14.712 \\
\hline ÖRKAR12 & 0.910 & & 39.892 & İÇİŞTAT12 & 0.767 & 0.087 & 14.997 \\
\hline ÖRKAR13 & 0.874 & 0.028 & 35.4 & DIŞiș & 0.643 & - & - \\
\hline \multicolumn{4}{|c|}{ Duygusal Bağlılık Ölçeği } & DIŞIŞTAT2 & 0.617 & 0.045 & 23.746 \\
\hline DUYBAĞ1 & 0.466 & 0.043 & 12.121 & DIȘiȘTAT3 & 0.779 & 0.060 & 16.506 \\
\hline DUYBAĞ2 & 0.402 & 0.045 & 10.212 & DIŞiŞTAT4 & 0.674 & 0.069 & 14.680 \\
\hline DUYBAĞ4 & 0.888 & 0.031 & 32.359 & DIŞİSTAAT5 & 0.819 & 0.069 & 17.167 \\
\hline DUYBAĞ5 & 0.935 & 0.029 & 35.633 & DIŞișTAT6 & 0.667 & 0.049 & 14.561 \\
\hline \multirow[t]{2}{*}{ DUYBAĞ6 } & 0.897 & - & - & DIŞiŞTAT7 & 0.693 & 0.070 & 15.034 \\
\hline & & & & DIŞIȘTAT8 & 0.744 & 0.055 & 15.905 \\
\hline
\end{tabular}

Faktör analizi sonucunda elde edilen uyum iyiliği değerleri Tablo 3 'de gösterilmektedir.

\section{Tablo 3: Uyumu İyiliği Değerleri}

\begin{tabular}{|l|c|c|c|c|c|c|}
\hline Uyum İyiliği Kriteri & $(\chi 2 / \mathrm{sd})$ & GFI & NFI & TLI & CFI & RMSEA \\
\hline Uyum İyiliği Değeri & 3.652 & 0.847 & 0.908 & 0.924 & 0.931 & 0.066 \\
\hline Kabul Değeri & $\leq 5.000$ & $\geq 0.850$ & $\geq 0.900$ & $\geq 0.900$ & $\geq 0.900$ & $\leq 0.080$ \\
\hline
\end{tabular}

Tablo 3'e göre ise $\chi 2$ /sd değeri 3.652, GFI değeri 0.847, NFI değeri 0.908, TLI değeri 0.924 , CFI değeri 0.931 ve RMSEA değeri 0.066 olarak tespit edilmiştir. Uyumu iyiliği değerleri kapsamında GFI değerinin kabul değerinin çok az altında olduğu görülmekte, diğer uyum iyiliği değerlerinin ise kabul sınırının üzerinde olduğu görülmektedir. Bu veriler çerçevesinde örgütsel kariyer yönetimi ölçeği için tek faktörlü (13 ifade), duygusal bağlılık ölçeği için tek faktörlü (5 ifade) ve iş tatmini ölçeği için iki faktörlü (12 ifade içsel iş tatmini, 8 ifade dişsal iş tatmini) yapı doğrulanmıştır. 
Yapı geçerlilikleri sağlanan ölçeklerin güvenilirlikleri ise Cronbach Alfa $(\alpha)$ değerinin hesaplanması ile tespit edilmiştir. Analiz sonucunda elde edilen güvenilirlik değerleri Tablo 4'de sunulmaktadır.

\section{Tablo 4: Güvenilirlik Değerleri}

\begin{tabular}{|l|c|c|}
\hline Ölçek / Boyut & Madde Sayısı & Güvenilirlik Değeri \\
\hline Örgütsel Kariyer Yönetimi & 13 & 0.943 \\
\hline Duygusal Bağlılık & 5 & 0.859 \\
\hline İş Tatmini (Genel) & 20 & 0.950 \\
\hline İçsel İş Tatmini & 12 & 0.928 \\
\hline Dışsal İş Tatmini & 8 & 0.890 \\
\hline
\end{tabular}

Tablo 4'de sunulan değerler incelendiğinde, tüm ölçeklerin ve alt boyutların güvenilirlik değerinin 0.70 üzerinde olduğu görülmektedir. Dolayısıyla çalışma kapsamında kullanılan tüm ölçeklerin güvenilirlikleri sağlanmıştır (Nunnally ve Bernstein, 1994, s. 265).

\subsection{Tanımlayıcı İstatistikler}

Tanımlayıcı istatistikler kapsamında, çalışmada kullanılan değişkenlere ilişkin ortalama, standart sapma ve korelasyon değerleri incelenmektedir. Tanımlayıcı değerler Tablo 5'de gösterilmektedir.

Tablo 5: Ortalama, Standart Sapma ve Korelasyon Değerleri

\begin{tabular}{|l|l|c|c|c|c|c|c|c|}
\hline & Değişken & Ort. & S.S. & $\mathbf{1}$ & $\mathbf{2}$ & $\mathbf{3}$ & $\mathbf{4}$ & $\mathbf{5}$ \\
\hline $\mathbf{1}$ & Örgütsel Kariyer Yön. & 3.414 & 1.133 & - & & & & \\
\hline $\mathbf{2}$ & Duygusal Bağlılık & 3.622 & 0.874 & $0.589^{* *}$ & - & & & \\
\hline $\mathbf{3}$ & Genel İş Tatmini & 3.810 & 0.702 & $0.676^{* *}$ & $0.652^{* *}$ & - & & \\
\hline $\mathbf{4}$ & İçsel İş Tatmini & 3.773 & 0.709 & $0.610^{* *}$ & $0.623^{* *}$ & $0.968^{* *}$ & - & \\
\hline $\mathbf{5}$ & Dişsal İş Tatmini & 3.866 & 0.773 & $0.695^{* *}$ & $0.622^{* *}$ & $0.938^{* *}$ & $0.821^{* *}$ & - \\
\hline
\end{tabular}

$\mathrm{N}=607, * * \mathrm{p}<0,01$

Tablo 5'de yer alan ortalamalara göre dişsal iş tatmininin içsel ve genel iş tatminine göre daha yüksek olduğu görülmektedir. Bununla birlikte çalışanların en düşük algılarının örgütsel kariyer yönetimine ilişkin olduğu belirlenmiştir. Genel olarak değişkenler arasındaki ilişkilere bakıldığında ise çalışma kapsamında kullanılan tüm değişkenler arasındaki karşılıklı ilişkilerin anlamlı $(\mathrm{p}<0.01)$ olduğu görülmektedir. $\mathrm{Bu}$ nedenle değişkenler arasında önemli etkiler öngörülebilmektedir. 


\subsection{Hipotez Testleri}

Araştırmanın kapsamında oluşturulan hipotezler hiyerarşik regresyon analizi ile test edilmiştir. Analizlerde cinsiyet, yaş, medeni durum, öğrenim durumu aylık gelir, işyerinde çalışma süresi ve pozisyon değişkenleri kontrol değişkenleri olarak kullanılmıştır. Analiz sonucunda elde edilen bulgular Tablo 6'da gösterilmektedir.

Çalışma kapsamında ilk hipotez çalışanların örgütsel kariyer yönetimi faaliyetlerine ilişkin algılarının iş tatminini (genel iş tatmini, içsel iş tatmini, dışsal iş tatmini) nasıl etkilediğini belirlemeye yöneliktir. Regresyon analizi sonucunda (1. Aşama), çalışanların algıladığı örgütsel kariyer yönetimi faaliyetlerinin genel iş tatminini (H1a: $\beta=0.592, \mathrm{p}<0.01)$, içsel iş tatminini $(\mathrm{H} 1 \mathrm{~b}: \beta=0.508, \mathrm{p}<0.01)$ ve dışsal iş tatminini $(\mathrm{H} 1 \mathrm{c}: \beta=0.644, \mathrm{p}<0.01)$ pozitif yönlü ve anlamlı olarak etkilediği tespit edilmiştir. Dolayısıyla çalışmanın ilk hipotezi kabul edilmiştir.

Tablo 6: Regresyon Analizi Sonuçları

\begin{tabular}{|c|c|c|c|c|c|c|c|}
\hline & Genel İş & İçsel İş & Dişsal İş̧ & \multicolumn{4}{|c|}{ Duygusal Bağlılık } \\
\hline & \multicolumn{3}{|c|}{ 1. Aşama } & 2. Aşama & \multicolumn{3}{|c|}{ 3. Aşama } \\
\hline & $\beta$ & $\beta$ & $\beta$ & $\beta$ & $\beta$ & $\beta$ & $\beta$ \\
\hline \multicolumn{8}{|l|}{ Kontrol Değişkeni } \\
\hline Cinsiyet & 0.009 & 0.014 & 0.001 & -0.010 & -0.013 & -0.015 & -0.010 \\
\hline Yaş & 0.020 & 0.071 & -0.053 & -0.017 & -0.025 & -0.043 & 0.001 \\
\hline Medeni durum & -0.063 & -0.052 & -0.071 & -0.061 & -0.036 & -0.042 & -0.036 \\
\hline Öğrenim durumu & -0.015 & 0.003 & -0.037 & -0.049 & -0.043 & -0.005 & -0.036 \\
\hline Aylık Gelir & 0.023 & 0.015 & 0.031 & 0.061 & 0.052 & 0.056 & 0.050 \\
\hline İşyerinde Çalış. Süre & $0.169 *$ & $0.177 *$ & $0.141 *$ & $0.284 * *$ & $0.217 * *$ & $0.220 * *$ & $0.235^{* *}$ \\
\hline Pozisyon & -0.058 & -0.080 & -0.022 & 0.065 & 0.088 & $0.094 *$ & 0.073 \\
\hline \multicolumn{8}{|l|}{ Bağımsız Değiş̌ken } \\
\hline Örgütsel Kariyer Yön. & $0.592 * *$ & $0.508 * *$ & $0.644 * *$ & $0.496 * *$ & $0.260 * *$ & $0.312 * *$ & $0.273 * *$ \\
\hline \multicolumn{8}{|l|}{ Aracı Değişken } \\
\hline Genel İş Tatmini & & & & & $0.400 * *$ & & \\
\hline İçsel İş Tatmini & & & & & & $0.362 * *$ & \\
\hline Dişsal İş Tatmini & & & & & & & $0.347 * *$ \\
\hline $\mathbf{R}^{2}$ & 0.517 & 0.463 & 0.507 & 0.426 & 0.503 & 0.497 & 0.486 \\
\hline Düzeltilmiş $\mathbf{R}^{2}$ & 0.510 & 0.456 & 0.500 & 0.419 & 0.496 & 0.489 & 0.478 \\
\hline F Değeri & $79.865 *$ & $64.399 *$ & 76.854* & $55.522 * *$ & $67.264 *$ & 65.429* & $62.629 *$ \\
\hline
\end{tabular}

$\mathrm{N}=202, * \mathrm{p}<0.05, * * \mathrm{p}<0.01$ 
İkinci hipotez ile çalışanlar tarafindan algılanan örgütsel kariyer yönetimi faaliyetlerinin duygusal bağllık üzerinde etkisi belirlenmeye çalışılmaktadır. Regresyon analizi sonucunda (2. Aşama), örgütsel kariyer yönetimi algısının duygusal bağll1ık üzerinde pozitif yönlü ve anlamlı bir etkisinin bulunduğu belirlenmiştir $(\mathrm{H} 2: \beta=0.496, \mathrm{p}<0.01)$. Bu bulgu ile çalışmanın ikinci hipotezi de kabul edilmiştir.

Üçüncü hipotez, iş tatminin (genel iş tatmini, içsel iş tatmini, dışsal iş tatmini) duygusal bağlllığı nasıl etkilediğini belirlemeye yöneliktir. Regresyon analizi sonucunda (3. Aşama), genel iş tatmini ( $\mathrm{H} 3 \mathrm{a}: \beta=0.400, \mathrm{p}<0.01)$, içsel iş tatmini $(\mathrm{H} 3 \mathrm{~b}: \beta=0.362, \mathrm{p}<0.01)$ ve dişsal iş tatmini $(\mathrm{H} 3 \mathrm{c}: \beta=0.347, \mathrm{p}<0.01)$ duygusal bağlılığı pozitif yönlü ve anlamlı olarak etkilemektedir. Dolayısıyla çalışmanın üçüncü hipotezi de kabul edilmektedir.

Dördüncü hipotez ise örgütsel kariyer yönetimi faaliyetlerine ilişkin algının duygusal bağll1ık üzerindeki etkisinde iş tatminin (genel iş tatmini, içsel iş tatmini, dışsal iş tatmini) aracılık rolünün bulunup bulunmadığını belirlemeye yöneliktir. Aracılık etkisi, Baron ve Kenny (1986) tarafından önerilen üç aşamalı regresyon süreci ile test edilmiştir. Baron ve Kenny (1986, s. 1176)'e göre aracilık etkisinden bahsedilmek için üç koşulun sağlanması gerekmektedir;

1. koşul: Bağımsız değişken (örgütsel kariyer yönetimi) aracı değişkeni (iş tatmini) anlamlı olarak etkilemelidir.

2. koşul: Bağımsız değişken (örgütsel kariyer yönetimi) bağımlı değişkeni (duygusal bağl1lık) anlamlı olarak etkilemelidir.

3. koşul: Üçüncü aşamada aracı değişken (iş tatmini) modele eklendiğinde, bağımsız değişkenin (örgütsel kariyer yönetimi) bağımlı değişken (duygusal bağll1ık) üzerindeki etkisi düşerken veya anlamsızlaşırken, aracı değişkenin (iş tatmini) bağımlı değişken (duygusal bağılık) üzerinde anlamlı bir etkisi olmalıdır.

Bağımsız değişkenin bağımlı değişken üzerindeki etkisinin anlamsızlaşması tam aracılık etkisinin bulunduğu, etkinin derecesinin düşmesi ise kısmi aracılık etkisinin bulunduğu anlamına gelmektedir (Baron ve Kenny, 1986, s. 1177).

Analizler sonucunda, örgütsel kariyer yönetiminin hem iş tatmini (genel iş tatmini, içsel iş tatmini, dışsal iş tatmini) üzerindeki hem de duygusal bağlllık üzerindeki etkisinin anlamlı olduğu tespit edilmiştir. Dolayısıyla aracılık etkisi için gerekli olan birinci ve ikinci koşul sağlanmaktadır. Üçüncü koşul şartı için ise hipotez testlerinin üçüncü aşamasında aracı değişken olarak genel iş tatmini, içsel iş tatmini ve dişsal iş tatmini teker teker modele eklenmiştir. Her üç regresyon analizinde de aracı değişkenlerin modele eklenmesiyle örgütsel kariyer yönetiminin duygusal bağllık üzerindeki etkisi yine anlamlı olmuştur, fakat etki derecesi azalmıştır. Dolayısıyla genel iş tatmininin, içsel iş tatmininin ve dışsal iş 
tatmininin örgütsel kariyer yönetiminin duygusal bağlılık üzerindeki etkisinde k1smi aracılık etkisi bulunmaktadır.

Bununla birlikte kısmi aracılık etkisinin anlamlılığını belirleyebilmek için Sobel testi uygulanmıştır (Sobel, 1982). Sobel testi sonucunda örgütsel kariyer yönetiminin duygusal bağlllık üzerindeki etkisinde genel iş tatmininin ( $Z=15.318$, $\mathrm{p}<0.01)$, içsel iş tatmininin $(Z=13.691, \mathrm{p}<0,01)$ ve dışsal iş tatmininin $(Z=15.070$, $\mathrm{p}<0.01)$ kısmi aracılık etkisi anlamlı bulunmuştur. Dolayısıyla çalışmanın dördüncü hipotezi de kabul edilmektedir.

\section{Sonuç}

Bu çalışmada örgütsel kariyer yönetiminin duygusal bağlılık üzerindeki etkisinde iş tatmininin (genel iş tatmini, içsel iş tatmini, dışsal iş tatmini) aracılık rolü araştırılmış olup üretim ve hizmet sektörü temel alınmıştır. Çalışma; farklı üretim ve hizmet dallarında faaliyette bulunan işletmelerde gerçekleştirilmiştir.

Belirtilen amaçla gerçekleştirilen bu çalışmanın, günümüzde hızla artan teknolojik gelişmeler, değişen rekabet koşulları ve tüketici algısında meydana gelen hızlı değişmelerin, işletmelerin faaliyette bulunduğu alanlarda meydana gelen gelişmelere uyum sağlama ve adapte olmada, maddi sermayenin olduğu kadar maddi olmayan sermayenin en önemlisi olan işgörenlerin, iş tatmininin önemini belirleme açısından yol gösterici olacağı ve katkı sağlayacağı düşünülmektedir. İşletmelerin rekabet üstünlüğü sağlaması, sürekliliklerini koruması ve gelişmeleri için teknoloji, kalite, sermaye gibi unsurlarının yanı sıra bunları gerçekleştirecek olan işgörenlerin önemi yadsınamaz. İşletmeler nitelikli, belirli yeterlilik ve yetkinliklere sahip olan işgörenleri işletmelerinde tutmak ve yeni işgörenleri işletmelerine kazandırmak için birçok faaliyette bulunmaktadır. Diğer taraftan işgörenlerin beklentileri de sosyal hayatın gelişmesi, yaşam standartlarının artmas1, bilginin daha hizlı elde edilmesi gibi nedenlerden dolay1 farklılaşmaktadır. Bu beklentileri sağlamak işletmelerin önemli görevleri arasında yer almaktadır. Günümüzde işletmeler işgörenlerinin maddi beklentileri yanında maddi olmayan beklentilerini de karşılamak için çeşitli faaliyetlerde bulunmaktadır. İşgörenlerine kariyer olanakları sunamayan, duygusal olarak bağlılık duygusunu sağlayamayan, performansın ve örgütsel bağlılığın önemini kavrayamayan, iş tatminini sağlayamayan işletmelerin rekabet edebilmeleri ve hayatta kalmaları beklenemez.

$\mathrm{Bu}$ çalışmada, oluşturulan hipotezler, regresyon analizi; kullanılan ölçeklerin yapı geçerliliği doğrulayıcı faktör analizi ile test edilmiştir.

Çalışma; gıda, kâğıt, makine, yedek parça, inşaat ve yapı malzemeleri ile perakende, restoran ve otel sektöründe faaliyette bulunan işletmelerde farklı seviyelerde çalışmakta olan işgörenler üzerinde gerçekleştirilmiş olup, 
işgörenlerin örgütsel kariyer yönetiminin, duygusal bağlllık üzerindeki etkisinde farklı boyutlara iliş̧in iş tatmini seviyeleri araştırılmıştır.

Çalışmaya demografik faktörler açısından bakıldığında katılımcıların;

- Büyük çoğunluğunun erkek, eğitim seviyelerinin ise yüksek olduğu,

- İşyerinde çalışma sürelerine bakıldığında on yıl ve üzeri çalışanların on yildan az çalışanlara oranla düşük olduğu,

- Yaş açısından bakıldığında ise orta yaş ve üzeri olanların yüksek olduğu,

- Çalışanların büyük çoğunluğunun alt kademe yönetici pozisyonunda olduğu görülmektedir.

İkinci olarak, dışsal iş tatmininin içsel ve genel iş tatminine göre yüksek olduğu belirlenmiş̧ir.

Dışsal iş tatminin altında bulunan maddeler; takdir edilme, çalışma koşulları, yaratıcılık, sorumluluk, yükselme, ücret gibi işin çevresine ait öğelerden oluşturmaktadır (Weiss vd. 1967, 4; Karadağ vd. 2009, 35). Bununla beraber işgörenlerin en düşük algılarının örgütsel kariyer yönetimiyle ilgili olduğu belirlenmişsir.

Elde edilen bulgular değerlendirildiğinde, ilk olarak, işgörenler tarafindan algılanan örgütsel kariyer yönetimi faaliyetleri iş tatminini pozitif ve anlamlı olarak etkilemektedir. $\mathrm{Bu}$ bulgunun literatürde bulunan diğer çalışmaları desteklediği görülmektedir. Bu anlamda Demir ve Çini’nin (2014) banka çalışanları üzerinde yaptıkları araştırma sonucuna göre, bankanın işgörenlere kariyer firsatları sunması ve buna bağlı olarak işgörenlerin iş tatmini sağlanarak örgüte olan bağlılıklarının da arttı̆̆ sonucunu ortaya koymaktadır. Ay vd. (2014)'ün sağlık çalışanları üzerinde yaptı̆̆ araştırma sonucuna göre, kariyer yönetimi ve iş tatmini arasında pozitif ilişki olduğunu ortaya koymaktadır. İşletmelerin varlıklarını devam ettirebilmeleri, üstünlük sağlayabilmeleri ve gelişen küresel ölçekte kendilerine yer bulabilmeleri için en önemli sermayeleri insan yani işgörenleridir. İşletmeler, işgörenlerinin beklentilerini karşılayacak şekilde belirlemiş oldukları kariyer yönetimi uygulamaları sayesinde işgörenlerinin tatmin düzeylerini arttırarak işletmelerinin gelişmesine katkı sağlayacaklardır. İş tatmini sağlanmış olan bir işgören kendini işletmenin bir parçası olarak görüp, sahip olduğu yetkinliği en iyi şekilde kullanarak hem kendi verimliliğini arttırmak hem de bunu yaptığ 1 işe yansıtarak ürettiği mal ve hizmetin kalitesine katkı sağmaktadır.

İkinci olarak, işgörenler tarafindan algılanan örgütsel kariyer yönetimi faaliyetleri, duygusal bağl1lığı pozitif yönde ve anlamlı olarak etkilediği görülmektedir. Elde 
edilen bu bulgu, Küçük (2012) tarafından yapılan çalışmayı da destekler niteliktedir. İşletmeler belirlemiş oldukları hedef ve politikalarla geleceğe daha emin adımlarla ilerlerken, bu hedef ve politikalar işgörenler tarafından bir zorunluluğun ötesinde bireysel bir amaç olarak benimsendiğinde işletmenin büyüme hızı ve gelecekle ilgili hedefleri daha emin adımlarla sağlanmış olur. Belirtilen hususları sağlamak için gerçekleştirilen birçok politikadan biri olan kariyer yönetiminin bu amacın gerçekleşmesinde önemli bir yeri ve önemi vardır. Çünkü işgörenlerin kişisel beklentileri ile işletmenin hedefleri düzgün planlanmış kariyer yönetimi yoluyla sağlanırsa, işgörenlerin beklentileri gerçekleşirken işletmeye bakış açıları da farklılaşacaktır. Böylece hem işletmelerin belirlemiş olduğu hedefler gerçekleşecek, hem de işgörenler işletmenin belirlemiş olduğu politika ve hedefleri daha fazla benimsemiş olacaklardır.

Üçüncü olarak, iş tatminin duygusal bağlılı̆g pozitif ve anlamlı olarak etkilediği görülmektedir. Bulunan bu sonuç diğer çalışmaları desteklemektedir. Poyraz ve Kama (2008), Kılıç (2008), Williams ve Hazer (1986) tarafından yapılan çalışmalarda iş tatminin duygusal bağlılığı etkilediğini, duygusal bağlılığında bütün olarak örgütsel bağlılık boyutunda ele alındığında iş tatminini etkilediğini göstermiştir. Yapılan araştırmalar incelendiğinde iş tatmini yüksek olan işgörenler örgütlerine olan duygusal bağlılık düzeyleri daha fazla olduğu belirlenmiştir. İşgörenlerin tatmin seviyeleri arttıkça işletmeye olan bakış açıları, beklenti düzeyleri ve en önemlisi bağlılık seviyeleri artmaktadır. Duygusal bağlılığ işgörenlerin sergilemiş olduğu performans seviyeleri de artmaktadır.

Çalışma kapsamında elde edilen bulgular genel olarak değerlendirildiğinde ise örgütsel kariyer yönetiminin işletmelerde işgörenlerin iş tatminleri sağlamada önemli bir rol oynadığı görülmektedir. İşletmeler varlıklarını devam ettirebilmek için genişleyen pazarlarda rakiplerinden önde olmak için pazar koşulları, müşteri memnuniyeti, sundukları mal ve hizmetlerin kalitesi gibi birçok unsurla hayatta kalmak ve varlıklarını devam ettirmek durumundadırlar. Bunları sağlamak için sahip oldukları teknoloji, kullandıkları ileri teknoloji yazılımların önemi kadar tüm bu unsurları sağlayacak olan nitelikli, yetkin ve belirli uzmanlığa sahip olan işgörenlerinin de varlığı yadsınamayacak derecedir. İşletmeler gelecekle ilgili planlar yaparken bu plan ve stratejilerinde işgörenlerinin varlığı ve önemi her geçen gün artarak devam etmektedir. İşletmelerde uygulanan politikalar işgörenlerin istek ve ihtiyaçlarını temel alarak belirlenmelidir. İyi bir kariyer planlaması yapılan işletmelerde, işletmenin uygulayacağı politikalara karşı işgörenlerin tutum ve davranışları daha yatkın olacaktır. İş tatmini sağlanmış bir işgörenin işletmeye sağlayacağı katkı ve fayda seviyesi oldukça fazladır. İş tatmini sağlanmış bir birey, bireysel açıdan kariyer hedefiyle örgütün belirlemiş olduğu kariyer hedefinin örtüştügünü kabullenmiştir. Tatmin olmuş işgören, kendini işletmenin bir parçası sayarak işletmeye duygusal açıdan daha fazla bağlanmış olacaktır. İşletmeler insan kaynakları politikalarını belirlerken iş tatmininin önemini kavrayarak uygulanabilir bir yöntem belirlemelidir. İşgörenleri 
işletme için bir değer olarak göremeyen işletmeler, gelecek hedefleri konusunda başarılı olma şansları, günümüz koşullarında gerçekleşmesi düşünülen bir beklenti olamamaktadir.

\section{Kaynakça}

Akgündüz, Y. (2013). Konaklama işletmelerinde iş doyumu, yaşam doyumu ve öz yeterlilik arasındaki ilişkinin analizi. Celal Bayar Üniversitesi Sosyal Bilimler Dergisi, 11(1), 180-204.

Allen, N. J. ve Meyer, J. P. (1990). The measurement and antecedents of affective, continuance and normative commitment to the organization. Journal of Occupational and Organizational Psychology, 63(1), 1-18.

Altunışık, R., Coşkun, R., Bayraktaroğlu, S. ve Yıldırım, E. (2005). Sosyal bilimlerde araştırma yöntemleri: SPSS uygulamalı, 4. Bask1. İstanbul: Avc1 Ofset.

Anderson, J. C. ve Gerbing, D. W. (1988). Structural equation modeling in practice: a review and recommended two-step approach. Psychological Bulletin, 103(3), 411-423.

Aytaç, S. (2005). Çalışma yaşamında kariyer yönetimi planlaması geliştirilmesi sorunlart, İstanbul: Epsilon Yayınları.

Ay, F. A., Filizöz, B. ve Öncül, M. S. (2014). Kariyer yönetimi uygulamalarının iş tatminine etkisi: kamu ve özel sağlık çalışanlarına yönelik bir araştırma. Afyon Kocatepe Üniversitesi İktisadi ve İdari Bilimler Fakültesi Dergisi, 16(2), 45-61.

Baron, R. M. ve Kenny, D. A. (1986). The moderator-mediator variable distinction in social psychological research: Conceptual, strategic, and statistical considerations. Journal of Personality and Social Psychology, 51(6), 1173-1182.

Bateman, T.S. ve Strasser, S. (1984). A longitudinal antecedents of organizational commitment. Academy of Management Journal, 27(1), 95-112.

Bingöl, D. (2016). Insan kaynakları yönetimi, 10. Baskı, İstanbul: Beta Yayınları.

Bolat O. İ. ve Bolat, T. (2008). Otel işletmelerinde örgütsel bağlilık ve örgütsel vatandaşlık davranışı ilişkisi. Balıkesir Üniversitesi Sosyal Bilimler Enstitüsü Dergisi, 11(19), 75-94.

Bowin, R. B. ve Harvey, D. (2000). Human resource management: An experiential approach, 2nd Edition, New Jersey: Prentice Hall.

Brown, S. P. ve Peterson, R. A. (1993). Antecedents and consequences of salesperson job satisfaction: Meta-analysis and assessment of causal effects. Journal of Marketing Research, 30(1), 63-77. 
Byrne, B. M. (2010). Structural equation modeling with AMOS: Basic concepts, applications and programming, 2nd Edition, New York: Routledge Taylor and Francis Group.

Carleton, K. (2011). How to motivate and retain knowledge workers in organizations: A review of the literature. International Journal of Management, 28(2), 459-468.

Cengiz, A. A. (2002). Örgüt Yaşamında örgütsel bağlılı̆̆ın belirleyicileri ve eskişehir bölgesinde doktor ve hemşire meslek gruplarl arasinda karşılaştırmalı bir çalışma. 10.Ulusal Yönetim ve Organizasyon Kongresi, Akdeniz Üniversitesi İktisadi ve İdari Bilimler Fakültesi, Yayın No:4.

Çetin, M. Ö. (2004). Örgüt kültürü ve örgütsel bağglllk, Ankara: Nobel Yayınları.

Demir, M. E. ve Çini, M. A. (2014). Konya bankacılık sektöründe eğitim ve kariyer firsatları açısından iş tatmininin örgütsel bağlılık üzerine etkisi. Selçuk Üniversitesi Sosyal Bilimler Meslek Yüksekokulu Dergisi, 14(1-2), 161-171.

Doğanalp, B. (2012). İnsan kaynakları seçme sürecinde bulanık mantık yaklaşımı: Görgül bir araştırma. Yayınlanmış Doktora Tezi, Selçuk Üniversitesi Sosyal Bilimler Enstitüsü, Konya.

Duman, G. (2000). Yönetim açısından iş tatmini. Yayınlanmamış Yüksek Lisans Tezi, Anadolu Üniversitesi Sosyal Bilimler Enstitüsü, Eskişehir.

Eisenberg, E. M., Monge, P. R. ve Miller, K. I. (1983). Involvement in communication networks as a predictor of organizational commitment. Human Communication Research, 10(2), 179-201.

Emre, G. (2016). İş tatmini ve örgütsel bağlllık etkileşimi: istanbul ili lojistik firmaları çalışanları üzerine bir uygulama. Yayınlanmamış Yüksek Lisans Tezi, İstanbul Gelişim Üniversitesi Sosyal Bilimler Enstitüsü, İstanbul.

Erdoğan, İ. (1994). İşletmelerde davranış, Beta Basım Yayın, İstanbul.

Erdoğmuş, N. (2003). Kariyer geliştirme: Kuram ve uygulama, Ankara: Nobel.

Eren, E. (2004). Örgütsel davranış ve yönetim psikolojisi, İstanbul: Beta Basım Yayım Dağıtım.

Etzioni, A. (1975). A Comprehensive analysis of complex organizations, New York: Free Press.

Fındıkçı, İ. (2009). Insan kaynakları yönetimi, 7. Baskı, İstanbul: Alfa Yayınları.

Ghani, K. A., Jayabalan, V. ve Sugumar, V. (2002). Impact of advanced manufacturing technology on organizational structure. The Journal of High Technology Management Research, 13, 157-175 
Greenhaus, J. H., Callanan, G. A. ve Kaplan, E. (1995). The role of goal setting in career management. International Journal of Career Management, 7(5), 312.

Günlü, E, Aksaraylı, M. ve Perçin, N. (2010). Job satisfaction and organizational commitment of hotel managers in Turkey. International Journal of Contemporary Hospitality Management, 22(5), 693-717.

Gürkan, Ç. (2006). Örgütsel bağglllk: örgütsel iklimin örgütsel bağlllık üzerindeki etkisi ve Trakya Üniversitesi'nde örgüt iklimi ile örgütsel bă̆lllık arasındaki ilişkinin araştırılması. Yayımlanmamış Yüksek Lisans Tezi, Trakya Üniversitesi Sosyal Bilimler Enstitüsü, Edirne.

Hsiao, J.-M. (2013). Organizational career management, job satisfaction and organizational commitment: A Case Study of Car Dealer in Taiwan. Actual Problems of Economics, 141(3), 432-440.

Horwitz, F. M., Chan, T. H. ve Quazi, H. A. (2003). Finders, keepers? Attracting, motivating, and retaining knowledge workers. Human Resource Management Journal, 13(4), 23-44.

Kanter, R.M. (1968). Commitment and social organizations. American Sociological Review, 33(4), 499-517.

Karadağ, E., Başaran, A. ve Korkmaz, T. (2009). İlköğretim okulu öğretmenlerinin algıladıkları liderlik biçimleri ile iş doyumları arasındaki ilişki. Balıkesir Üniversitesi Sosyal Bilimler Enstitüsü Dergisi, 12(21), 3245.

Karaduman, A. (2002). Ekip çalışmasında liderin iş tatmini üzerindeki Etkisi. Yayımlanmamış Yüksek Lisans Tezi, Atatürk Üniversitesi Sosyal Bilimler Enstitüsü, Erzurum.

Katz, D. ve Kahn, R. L. (1977). Örgütlerin Toplumsal psikolojisi, (Çev: H. Can, Y. Bayar) Ankara: TODAİE.

Kaya, Ç. ve Ceylan, B. (2014). An empirical study on the role of career development programs in organizations and organizational commitment on job satisfaction of employees. American Journal of Business and Management, 3(3), 178-191.

Kılıç, G. (2008). Kariyer yönetimi ve örgütsel bağlllık arasındaki ilişki: Beş yıldızlı otel işletmelerde bir araştırma. Yayımlanmamış Doktora Tezi, Gazi Üniversitesi Eğitim Bilimleri Enstitüsü, Ankara.

Kılıç, G. ve Öztürk, Y. (2009). Kariyer yönetimi: Beş yıldızlı otellerde bir uygulama. Anatolia: Turizm Araştırmaları Dergisi, 20(1), 45-60.

Küçük, M. (2012). Kariyer yönetimi ve örgütsel bağlllık arasındaki ilişki: banka çalışanları üzerindeki etkinin incelenmesi. Yayımlanmamış Yüksek Lisans 
Tezi, Çanakkale Onsekiz Mart Üniversitesi Sosyal Bilimleri Enstitüsü, Çanakkale.

Kwantes C. T. (2009). Culture, Job satisfaction and organizational commitment in India and the United States. Journal of Indian Business Research, 1(4), 196212.

Mayo, A. (1991). Managing careers in organizations, London: IPM.

Meydan, C. H. ve Şeşen, H. (2011). Yapısal eşitlik modellemesi: AMOS uygulamalar, Ankara: Detay Yayıncılık.

Meyer, J. P. ve Allen, N. J. (1991). A three-component conceptualization of organizational commitment. Human Resource Management Review, 1(1), 61-89.

Meyer, J. P. ve Smith, C. (2000). HRM practices and organizational commitment: Test of a mediation model. Canadian Journal of Administrative Sciences, 17(4), 319-331.

Meyer, J. P., Allen, N. J. ve Smith, C. A. (1993). Commitment to organizations and occupations: Extension and test of a three-component conceptualization. Journal of Applied Psychology, 78(4), 538-551.

Meyer, J. P., Stanley, D. J., Herscovitch, L. ve Topolnytsky, L. (2002). affective, continuance, and normative commitment to the organization: A metaanalysis of antecedents, Correlates, and Consequences. Journal of Vocational Behavior, 61(1), 20-52.

Mowday, R. T., Steers, R. M. ve Porter, L. W. (1979). The Measurement of organizational commitment. Journal of Vocational Behavior, 14(2), 224247.

Mowday, R. T., Porter, L. W. ve Steers, R. M. (1982). Employee-organization linkages: the psychology of commitment, absenteeism and turnover. London: Academic Press.

Nijhof, W. J., de Jong, M. J. ve Beukhof, G. (1998). Employee commitment in changing organizations: An exploration. Journal of European Industrial Training, 22(6), 243-248

Noe, R. A. (2009). Insan kaynaklarının eğitimi ve geliştirilmesi, 4. Baskı, (Çev.: Canan Çetin), İstanbul: Beta Basım Yayım Dağıtım.

Nunnally, J. C. ve Bernstein, I. H. (1994). Psychometric theory, 3rd Edition, New York: McGraw-Hill Inc.

O'Reilly, C. ve Chatman, J. (1986). Organizational commitment and psychological attachment: The effects of compliance, identification and internalization on prosocial behavior. Journal of Applied Psychology, 71(3), 492-499. 
Orpen, C. (1994). The Effects of organizational and individual career management on career success. International Journal of Manpower, 15(1), 27-37.

Örücü, E., Yumuşak, S. ve Bozkır, Y. (2006). Kalite yönetimi çerçevesinde bankalarda çalışan personelin iş tatmini ve iş tatminini etkileyen faktörlerin incelenmesine yönelik bir araştırma. Yönetim ve Ekonomi, 13(1), 39-51.

Özdevecioğlu, M. (2003). Algılanan örgütsel destek ile örgütsel bağlılık arasındaki ilişkilerin belirlenmesine yönelik bir araştırma. Dokuz Eylül Üniversitesi İ.I.B.F. Dergisi, 18(2), 113-130.

Özgen, H., Öztürk, A., ve Yalçın, A. (2002). İnsan kaynakları yönetimi, Adana: Nobel.

Poyraz, K. ve Kama, B. (2008). Algılanan iş güvencesinin, iş tatmini, örgütsel bağlılık ve işten ayrılma niyeti üzerindeki etkilerinin incelenmesi. Süleyman Demirel Üniversitesi İktisadi ve İdari Bilimler Fakültesi Dergisi, 13(2), 143-164.

Reichers, A. E. (1985). A review and reconceptualization of organizational commitment. Academy of Management Review, 10(3), 465-476.

Sekaran, U. (2003). Research methods for business: A skill building approach, 4th Edition, New York: John Wiley\& Sons.

Sevimli, F. ve İşcan, Ö. F. (2005). Bireysel ve iş ortamına ait etkenler açısından iş doyumu. Ege Üniversitesi Akademik Bakış Dergisi, 5(1-2), 55-64.

Sobel, M. E. (1982). Asymptotic confidence intervals for indirect effects in structural equation models, Sociological Methodology, 13, 290-312.

Sturges, J., Guest, D., Conway, N. ve Davey, K. M. (2002). A longitudinal study of the relationship between career management and organizational commitment among graduates in the first ten years at work. Journal of Organizational Behavior, 23(6), 731-748.

Şimşek, M. Ş. (1998). Yönetim ve organizasyon, Konya: Mikro Dizgi.

Şimşek, M. Ş. ve Öge, H. S. (2014). İnsan kaynakları yönetimi, 6. Bask1, Konya: Eğitim Kitapevi Yayınları.

Şimşek, M. Ş., Çelik, A. ve Akatay, A. (2016). Insan kaynakları yönetimi ve kariyer uygulamaları, 3. Baskı, Konya: Eğitim Kitapevi Yayınları.

Tortop, N. (1994). Personel Yönetimi, 5. Baskı. Ankara: Yarg1 Yayınları.

Tuncer, P. (2012). Değişen insan kaynakları yönetimi anlayışında kariyer yönetimi, Ondokuz Mayıs Üniversitesi Ĕ̆itim Fakültesi Dergisi, 31(1), 203233. 
Ünver, Y. (2005). İşletmelerde kariyer yönetimi ve performans değerlendirme sistemleri, Ankara Üniversitesi, Sosyal Bilimler Enstitüsü, Dönem Projesi, Ankara.

Wasti, S.A. (2002). Affective and continuance commitment to the organization: test of an integrated model in the turkish context. International Journal of Intercultural Relations, 26(5), 525-550.

Weiss, D. J., Dawis, R. V., England, G. W. ve Lofquist, L. H. (1967). Manual for the minnesota satisfaction questionnaire. Minneapolis: University of Minnesota.

Wiener, Y. (1982). Commitment in organization: A normative view. Academy Management Review, 7, 122-129.

Williams, L. J., ve Hazer, J. T. (1986), Antecedents and consequences of satisfaction and commitment in turnover models: a reanalysis using latent variable structural equation methods. Journal of Applied Psychology, 71(2), 219-231.

Yahya, K. K., Othman, S. Z. ve Meruda N. (2004), Relationship between organizational career management and individual performance, International Journal of Management Studies, 11(2), 73-90. 


\title{
The Mediating Role of Job Satisfaction in the Effect of Organizational Career Management on Affective Commitment
}

\author{
Extended Abstract
}

\section{Introduction}

Organizational career management is a process that ensures the continuity of individual development, which enables employees to advance in their career processes and to meet the necessary support and training that will contribute to the development of employees. In general, career management is defined as a process by which individuals develop, implement and monitor career goals and strategies Greenhaus et al (1995). It is a series of human resource plans set down for the employees, which can satisfy the future needs of the organization. The basic purpose of the organizational career management is to let both employee and organization keep growing together. Through career management, the expectations and targets of the employees are integrated with the goals and objectives of the organization, so the satisfaction and commitment of the employees are increased. Thus, the employees show greater loyalty to the organization with increased sense of commitment and satisfaction. Job satisfaction is the employees 'satisfaction of the job itself, including the satisfaction to superior, type of work, career foreground and so on. The job satisfaction and organization commitment is one of hot topics which many enterprises who advocate the human-oriented point attention; it has an important meaning for theories 'development and enterprise management to research the job satisfaction and the organization commitment. This study focuses on the relationship between organizational career management, job satisfaction and affective commitment. The purpose of the study is to determine how career management practices perceived by employees effect the level of affective commitment with their organization and to determine whether the degree of job satisfaction mediates this relationship.

\section{Method}

The population of the research consists of the employees working in different enterprises operating in the production and service sectors. According to the information received from the enterprises, the research universe consists of 13240 people. The convenience sampling method was used to determine the participants. A total of 950 surveys were distributed to the employees taking into consideration the return rates. A total of 609 employees were returned and 2 surveys were found to be invalid. As a result, the sample of the study consists of 607 employees. The scale which is consist of 13 items and developed by Küçük (2012) was used to determine the degree of organizational career management activities perceived by employees. The "Minnesota Job Satisfaction Scale" developed by Weiss et al. (1967) was used to determine the degree of satisfaction of employees. Affective commitment is measured by a 6-item scale that adapted from Allen and Meyer (1990). Confirmatory factor analyses have been carried out to provide for the validity of research scales. Moreover, results of reliability analysis demonstrated that Cronbach'a Alpha levels of all the scales are above the acceptable level of 0.70 (Nunnally and Bernstein, 1994). The research hypotheses were tested by hierarchical regression analysis.

\section{Results and Discussion}

The main objective of this study was to advance the research on direct and indirect relationship between career management and organizational commitment. The results of this study confirm and extend prior findings on the relationship between organizational career management, job 
satisfaction and affective commitment. First, predictions relating to the direct effect of organizational career management on job satisfaction was confirmed. These results were similar to that of prior studies investigating the role of organizational career management on job satisfaction (Ay et al., 2014; Demir and Çini, 2014). It means that the career management practices which have identified to meet the expectations of the employees will increase the satisfaction level of the employees. Second, it is determined that organizational career management has a direct effect on affective commitment. It means, if the organizations provide their employees with more guidance and support and take the organizational career management as an important way to effectively manage, employees feel more committed to the organization. Third, it is determined that job satisfaction has a partial mediating effect on the relationship between organizational career management and affective commitment. That is, employees' perception of organizational career management may have more powerful impact on employees' affective commitment to the organization in the case of the feeling more job satisfaction.

\section{Conclusion}

The purpose of this study is to expand growing research on career management and organizational commitment. Specifically, this study found evidence that job satisfaction may be a critical intervening factor in the relationship between organizational career management and affective commitment. This study was conducted on full-time employees working in different enterprises operating in the production and service sectors. Thus, the present findings have important implications for all production and service organizations. In sum, by examining the relationship between organizational career management, job satisfaction and affective commitment, this study allows better positioned to predict why organizational career management results in increased affective commitment and provides some clues on how organizations can increase organizational commitment via job satisfaction. 